\title{
FAKTOR PERMINTAAN NON FUNGSIONAL GROUP MEMBER TERHADAP PERMINTAAN (SERI 1)
}

\author{
Iskandar Putong \\ Jurusan Manajemen, Fakultas Ekonomi dan Bisnis, Universitas Bina Nusantara \\ Jln. K.H. Syahdan No. 9, Palmerah, Jakarta Barat 11480 \\ putong304278@binus.ac.id
}

\begin{abstract}
Non-functional analysis of demand factors on demand for group members are aimed to discover whether there is significant impact of non functional variable demand potential purchasing decision. 3 independent variable for the Snob Effect of X1, X2 for the bandwagon effect and X3 for the Veblen Effect and a dependent variable $Y$ for Purchase Decision (Demand). The survey has 50 respondents and uses 21 item of a valid indicator. Analysis uses Pearson correlation model, Canonical Correlation and Hybrid intercorellation. The result of statistical analysis has proved the LOC by 95\%, shows that there is significant impact between variable of $X$ to $Y$ in a different format (trade off or trade on). Multivariate Canonical Correlation showed that the effect of variable $X$ to variable $Y$ at $0,27 \%$ whereas the effect of variable $Y$ to variable $X$ at $1 \%$
\end{abstract}

Keywords: non-functional demand, canonical correlation, hybrid inter-correlation

\begin{abstract}
Analisis non-fungsional dari faktor permintaan atas permintaan untuk anggota kelompok ditujukan untuk mengetahui apakah ada dampak yang signifikan dari variabel keputusan potensial pembelian kebutuhan non fungsional. 3 independen variabel untuk Efek Snob X1, X2 untuk efek bandwagon dan X3 untuk Pengaruh Veblen dan variabel terikat Y untuk Keputusan Pembelian (Demand). Survei ini memiliki 50 responden dan menggunakan 21 item dari indikator yang valid. Analisis menggunakan model korelasi Pearson, Korelasi Canonical dan interkorelasi Hybrid. Hasil analisis statistik telah membuktikan LOC senilai 95\% sehingga menunjukkan bahwa ada dampak yang signifikan antara variabel $X$ ke $Y$ dalam format yang berbeda (trade off atau trade on). Korelasi kanonikal multivariat menunjukkan bahwa pengaruh variabel $X$ ke $Y$ variabel sebesar $0,27 \% \%$ sedangkan pengaruh variabel $Y$ untuk variabel $X$ sebesar $1 \%$
\end{abstract}

Kata kunci: permintaan non-fungsional, korelasi kanonikal, interkorelasi hybrid 


\section{PENDAHULUAN}

Hukum Permintaan mentabiskan bahwa hargalah (ceteris paribus) yang menentukan besar kecilnya permintaan. Artinya, konsumen atau lebih tepatnya pembeli akan meningkatkan pembelian bila harga barang yang dimaksud untuk dibeli turun, demikian sebaliknya. Hukum ini ditahbiskan oleh Alfred Marshall berdasarkan pendekatan utilitas, dengan menggunakan metode matematik yang bersifat deduktif. Padahal bisa saja permintaan tidak akan meningkat dalam kondisi yang ceteris paribus meskipun harga turun, konsep matematika yang digunakan selalu berpatokan pada kesimbangan Pareto dan syarat rasional. Dengan demikian, bila seseorang yang memiliki uang Rp. 100 dan membeli barang X seharga Rp.10/unit, konsumen pasti mendapatkan 10 unit barang. Bila harga turun menjadi Rp. 5/unit, maka pasti mendapatkan 20 unit barang. Logika ini sebenarnyalah yang mengacaukan semua teori ekonomi dan turunannya, maka tak heran bila Ormerod mengatakan ilmu ekonomi sudah mati. Ada bagian penting yang bukan sekedar kondisi faktor permintaan yang diceteris paribus-kan yang sangat bepengaruh terhadap permintaan seseorang. Hal ini telah lama dijelaskan oleh Veblen, akan tetapi diabaikan oleh para ekonom mashab Cambridge, yaitu konsumsi budaya (efek pamer). Maksudnya, seorang akan membeli atau tidak membeli bukan karena harganya, akan tetapi apakah barang tersebut merupakan barang yang memberikan ia efek pamer terhadap lingkungannya atau tidak.

Efek pamer yang dimaksud saya tafsirkan bukan sekedar efek pamer yang sering dilakukan oleh orang kaya dan sangat kaya, akan tetapi justru efek pamer juga dilakukan oleh orang tak punya, miskin, bahkan melarat sekalipun. Kalau seseorang atau masyarakat meningkatkan pembelian atas suatu barang, bukan lantaran harganya relatif murah (seperti fenomena permintaan HP dewasa ini), akan tetapi permintaan itu memang karena didasarkan pada tuntutan atau trend yang sedang terjadi. Meskipun dalam kondisi ceteris paribus, konsumen tidak akan menaikkan permintaan bila barang yang dimaksud bukan barang konsumsi yang menjadi trend dan tidak memberikan efek pamer bagianya, dan sebaliknya faktor pamerlah yang justru meningkatkan permintaan meskipun harga barang naik (ceteris paribus).

Efek "ikut-ikutan" dan "gengsi" sangat berpengaruh pada permintaan dalam kondisi ceteris paribus nya hukum permintaan dan penawaran. Akan tetapi, berbeda dengan efek pamer (saya berani jamin bahwa setiap orang yang membeli suatu produk pastilah tujuannya untuk pamer, baik dalam bentuk dipajang, diceritakan, digambar, difoto atau semacamnya), makanya tidak aneh bila melihat keluarga miskin sekalipun bersedia untuk menghabiskan tabungannya (bahkan hutang) dalam rangka menyelenggarakan pesta sunatan anaknya demi bisa menyelenggarakan acara yang membuat kesan tidak malu-maluin kepada tetangganya) yang merupakan budaya masyarakat yang selalu menyertai dalam setiap konsumsinya, maka efek ikut-ikutan masih terpengaruh oleh harga. Konsumen melakukan permintaan bukan karena harganya, tetapi karena dorongan ikut-ikutan (bandwagon effect) oleh konsumen lainnya untuk membeli. Metode ini banyak dilakukan oleh produsen dalam bentuk iklan yang mempergunakan para selebritis, praktik ghost shoping, dan fashion. Pusat perbelanjaan pun menggunakan konsep ini untuk menarik pengunjung sebanyak-banyaknya. Pada intinya, efek inilah yang justru memberikan dampak pada permintaan. Efek pamer dan ikut-ikutan umumnya untuk kalangan derajat ekonomi apa saja bisa terjadi, akan tetapi efek gengsi adalah efek lain yang berpengaruh terhadap permintaan yang umumnya terjadi pada kalangan terbatas, misalnya orang kaya dan merasa kaya.

Efek Gengsi terhadap permintaan sehubungan dengan harga adalah bertolak belakang dengan hukum permintaan. Permintaan yang disebabkan karena efek gengsi justru akan meningkatkan permintaan pada saat harga barang tersebut naik (hal ini tidak berhubungan dengan barang Giffen), sebab naiknya atau tingginya harga barang dan mampu dibayar oleh konsumen menunjukkan status ekonominya di dalam kalangan masyarakat. 
Penelitian ini menindaklanjuti hasil penelitian sebelumnya tentang efek gengsi, ikut-ikutan, dan pamer terhadap permintaan yang dilakukan oleh Aloysius Albert Amanta pada tahun 2009 untuk proyek skripsinya, dan yang menjadi objek penelitiannya adalah para pelanggan Supermarket KemChicks di Pacific Palace Jakarta. Penelitiannya menggunakan alat analisis Korelasi Peringkat Spearman. Penelitian ini menggunakan data Kelompok Member yang sama, tetapi dengan perlakuan yang berbeda karena pada penelitian sebelumnya untuk data responden kelompok member, hasil tes menunjukkan sebarannya tidak normal. Dalam penelitian, agar berdistribusi normal, maka dilakukan pengurangan data yang Outliers. Tujuannya adalah untuk melihat apakah efek gengsi, ikut-ikutan, dan pamer memberikan pengaruhnya terhadap permintaan secara sendiri-sendiri, ataukah bersama-sama dan juga bagaimanakah efek interdependensi antar variabel tersebut.

Masalah dalam penelitian ini adalah "Seberapa besar pengaruh dan bagaimanakah efek mode, gengsi dan pamer pada permintaan (keputusan pembelian), baik secara dependensi maupun interdependensi?". Penelitian ini tidak mempermasalahkan variabel dummy yang menyebabkan munculnya efek gengsi, mode, dan pamer. Juga tidak mempermasalahkan jenis kelamin, status kewarganegaraan, tingkat pendidikan, dan status sosialnya dalam masyarakat. Penelitian ini menggunakan data kelompok member yang dilakukan penyesuaian atasnya tidak sebagaimana data yang digunakan Aloysius Albert Amanta dalam penelitiannya.

Tujuan penelitian ini adalah untuk mengetahui dan menganalisis tentang efek mode, gengsi dan pamer memberikan pengaruh pada keputusan pembelian dan bagaimanakah efek dari pengaruh itu, baik secara dependensi maupun interdependensi. Penelitian ini diharapkan memberikan manfaat pada para penjual dan calon penjual dalam menyikapi para konsumen (pelanggan dan calon pelanggan) sehingga ke depannya dapat dibentuk pola baru dalam menyiasati pemasaran yang efektif dan efisien.

Asumsi dalam penelitian ini adalah konsumen rasional dan realistis atas keputusan pembeliannya. Loading factor untuk variabel $\mathrm{Y}=1$. Adapun hipotesis dalam penelitian ini adalah:

Tabel 1 Hipotesis dalam Penelitian

\begin{tabular}{|c|c|}
\hline $\mathbf{H}_{01}$ & $\begin{array}{l}\text { Efek mode, gengsi, dan pamer tidak memberikan pengaruh (dependensi dan interdependensi) } \\
\text { yang signifikan terhadap keputusan pembelian }\end{array}$ \\
\hline $\mathbf{H}_{\mathbf{0 2}}$ & $\begin{array}{l}\text { Tidak ada pengaruh gabungan antara efek mode, gengsi, dan pamer terhadap keputusan } \\
\text { pembelian }\end{array}$ \\
\hline $\mathbf{H}_{\mathrm{a} 1}$ & $\begin{array}{l}\text { Efek mode, gengsi, dan pamer berpengaruh (dependensi dan interdependensi) secara } \\
\text { signifikan terhadap keputusan pembelian }\end{array}$ \\
\hline $\mathbf{H}_{\mathrm{a} 2}$ & $\begin{array}{l}\text { Efek mode, gengsi, dan pamer berpengaruh secara bersama-sama (gabungan) terhadap } \\
\text { keputusan pembelian }\end{array}$ \\
\hline
\end{tabular}

Hipotesis pertama diuji 2 arah dengan pendekatan induktif pada taraf keyakinan kemungkinan benar sebesar 95\%. Sedangkan hipotesis 2 diuji dengan pendekatan deduktif dengan ketentuan terdapat 2 gabungan atau lebih nilai faktor determinasi variabel bebas berjumlah $\leq 1$, lalu diuji dengan pendekatan induktif dengan taraf keyakinan kemungkinan benar sebesar 95\%.

Efek gengsi, ikut-ikutan, dan pamer dalam berkonsumsi adalah perilaku seseorang yang didasarkan pada sifat dan bawaan seseorang yang dipengaruhi oleh turunan, derajat kekayaan, dan lingkungan, sebagaimana yang diteorikan oleh James Duesenberry, yang menyatakan bahwa konsumsi seseorang itu selain dipengaruhi oleh pendapatannya, juga dipengaruhi oleh lingkungannya (Putong 1, 2003: 292). Dalam hal ini, yang mendasari ketiga efek yang diteliti adalah perilaku, dimulai dari perilaku konsumen. 
Menurut Laudon dan Bitta dalam (Aloysius, 2009:15-27), perilaku konsumen adalah proses pengambilan keputusan yang mensyaratkan aktivitas individu untuk mengevaluasi, memperoleh, menggunakan, atau mengukur barang dan jasa. American Marketing Association mendefinisikan perilaku konsumen sebagai "interaksi dinamis antara pengaruh dan kognisi, perilaku, kejadian di sekitar kita di mana manusia melakukan aspek pertukaran dalam hidup mereka." Jadi, perilaku konsumen adalah suatu proses untuk mengambil keputusan berdasarkan hasil evaluasi dan pengaruh, baik dari dalam maupun dari luar (Aloysius, 2009:15-27).

Faktor-faktor yang mempengaruhi keputusan pembelian konsumen antara lain budaya, kelas sosial, pribadi, keadaan ekonomi, dan psikologis (menurut Kotler dalam Aloysius, 2009:15-27). Keempat faktor ini akan membentuk dan memberikan efek gengsi, ikutan-ikutan, dan pamer kepada konsumen dalam memutuskan apakah akan membeli suatu barang atau tidak. Efek gengsi atau sering juga disebut sebagai efek ikut arus atau efek mode dengan menggunakan istilah Bandwagon Effect adalah efek yang memberikan dampak pada konsumen dalam melakukan permintaan, bukan saja disebabkan oleh harga, melainkan disebabkan juga oleh dorongan konsumen lain yang lebih dulu melakukan permintaan. Efek ikut-ikutan ini tidak berlaku untuk barang yang harganya terlalu tinggi dan juga terlalu rendah (Putong 2, 2009:48). Jadi, kurva permintaanya mengikuti pola hukum permintaan, akan tetapi terdapat batas atas dan batas bawah atas perubahan harga. Dalam konteks penelitian ini, persepsi konsumen menetapkan bahwa tempat mereka membeli adalah tempat yang menjual barang kebutuhannya, di mana harga tidak terlalu tinggi, akan tetapi juga tidak bisa dikatakan rendah atau murah untuk kalangan tertentu.

Dalam jurnal marketing (Roland Soong, vol. 9, 2002), dikatakan bahwa suatu pembeli mungkin dapat menekuni suatu bagian dari beberapa hal yang ada. Ketika korelasi positif, kita menghubungkannya dengan "bandwagon" effect dan ketika korelasi negatif, kita menghubungkannya dengan "reverse bandwagon". Kita menyusun atau membentuk suatu jadwal permintaan dalam suatu tempat yg dipenuhi efek dan dengan asumsi sederhana dari penawaran (Aloysius, 2009:15-27). Efek gengsi (snob effect) adalah efek yang memberikan dampak yang menurun pada permintaan bila harga suatu barang turun, meskipun tetap dalam konteks hukum permintaan akan tetapi sedikit berbeda, yaitu efek gengsi permintaannya bersifat inelastis; dalam artian nilai akhir dari permintaan akan semakin tinggi bila harga barangnya tinggi (Putong 2, 2009:50). Dalam konteks penelitian ini, persepsi konsumen menetapkan bahwa tempat mereka membeli adalah tempat yang menjual produk dengan harga yang relatif tinggi dan bergengsi.

Efek pamer (veblen effect) adalah efek yang menyebabkan seorang konsumen melakukan pembelian (mengkonsumsi) bila barang yang dibeli memberikan persepsi yang tinggi pada si pembeli, di mana tujuannya adalah untuk pamer. Umumnya, yang bisa dipamerkan dalam mengkonsumsi suatu produk adalah harganya. Makin tinggi harga, maka makin tinggi nilai pamernya sehingga itulah sebabnya konsumen ini akan meningkatkan pembeliannya, meksipun harganya naik. Dalam hal ini, kurva permintaan berslope positif (Putong 2, 2009:50). Dalam jurnal marketing oleh Laurie Simon Bagwell dan B. Douglas Bernheim tahun 2003 (Veblen effect in a theory of conspicious consumption). Veblen effect lahir dari sebuah desakan atau hasrat untuk mendapatkan suatu penghargaan dari status sosial ysng ditandai dengan kekayaan melalui "conspicious consumption", tetapi veblen effect tidak biasa lahir dari kepuasan "single crossing property". Mereka mungkin muncul ketika suatu property tersebut jatuh. Dalam kasus ini, "budget" merek adalah harga yang marjinal sehingga luxury brands tidak lagi superior atau terlihat mahal. Ketika suatu harga mahal akan membuat para pembeli mau untuk membeli karena melihat unsur luxury dan kekayaan di dalamnya (Aloysius, 2009:15-27).

Secara teoritis, terbentuknya harga karena adanya kebutuhan dan kelangkaan suatu produk. Kebutuhan dan kelangkaan menciptakan permintaan. Permintaan dalam efek non fungsional adalah bagian dari efek demonstrasi konsumen terhadap konsumen lainnya untuk menunjukkan jati dirinyanya (baik kaya maupun miskin). Oleh karenanya, permintaan konsumen juga berpengaruh 
terhadap nilai ikut-ikutan, rasa gengsi, dan keinginan untuk pamer yang merupakan bagian dari budaya manusia sepanjang hayat hidupnya (Putong 3, 2005:190-191).

\section{METODE PENELITIAN}

Sebagaimana data yang digunakan oleh Aloysius dalam proyek skripsinya, maka demikian jugalah dalam penelitian ini dengan sedikit perubahan. Objek penelitian ini adalah responden Supermarket X, berlokasi di Pacific Palace Jakarta Pusat. Pengambilan data dilakukan pada tahun 2009. Penelitian ini bersifat kuantitatif multivariate dengan jenis data primer (dalam konteks penelitian ini secara riel jenis data sekunder) dan digolongkan sebagai data interval, yang didapat dengan menggunakan instrumen kuesioner tertutup atas jumlah responden sebanyak minimal 91 orang (untuk kelompok member dan non member), yang ditentukan dari populasi sebanyak 1000 pelanggan. Ukuran rentang data menggunakan skala Likert yang bersifat semantic diferensial (1 terendah dan 7 tertinggi). Responden penelitian ini adalah kelompok member dengan ciri memiliki kartu anggota dan terdaftar aktif minimal 6 bulan mundur dari penelitian ini dilakukan. Terdapat 22 butir pernyataan yang harus diisi responden dan atasnya akan dilakukan uji kalibrasi untuk menentukan kelayakan instrumen dan kehandalan data.

Penentuan jumlah sampel menggunakan rumus Taro Yamane. Penentuan responden ditetapkan dengan cara Stratified Random Sampling dengan ketegori random sampling. Kuesioner disebar dengan menggunakan e-mail berdasarkan data dari pengelola Supermarket X, dengan ketentuan bila didapat kuesioner dikembalikan dan terisi penuh untuk masing-masing kelompok memenuhi kuota (91/2), maka hasil ini dianggap cukup, lebih dari itu tentu akan lebih baik. Alat analisis adalah Korelasi Pearson dan Canonical Correlation dan bila dimungkinkan digunakan metode Korelasi Hybrid untuk menjelaskan bagaimanakah efek yang diteliti berpengaruh terhadap keputusan pembelian. Pengolahan data menggunakan bantuan software Excel 2007. Berdasarkan data yang terkumpul, akan dipilah menjadi 4 variabel, yaitu 3 variabel bebas (X) dan 1 variabel tak bebas (Y) sebagai berikut:

$\mathrm{X} 1=$ Wagon effect /Ikut-ikutan/Ikut arus,

$\mathrm{X} 2=$ Snob effect /gengsi dan

$\mathrm{X} 3=$ Veblen effect $/$ pamer.

Sedangkan Y adalah keputusan pembelian (permintaan). Berdasarkan 3 variabel bebas dan 1 variabel terikat di atas, dapat dibuatkan paradigma penelitian dan tabelnya sebagai berikut:

Tabel 2 Paradigma Interkorelasi

\begin{tabular}{cccc}
\hline & $X 1$ & $X 2$ & $X 3$ \\
\hline$X 1$ & $R_{X 1 Y}$ & $R_{X 12}$ & $R_{X 13}$ \\
$X 2$ & & $R_{X 2 Y}$ & $X_{X 23}$ \\
$X 3$ & & & $R_{X 3 Y}$ \\
\hline
\end{tabular}

Ket: Variabel $\mathrm{X}$ hanya disimultankan terhadap $\mathrm{Y}$ bila memenuhi syarat $\sum \mathrm{R}^{2} \leq$ 


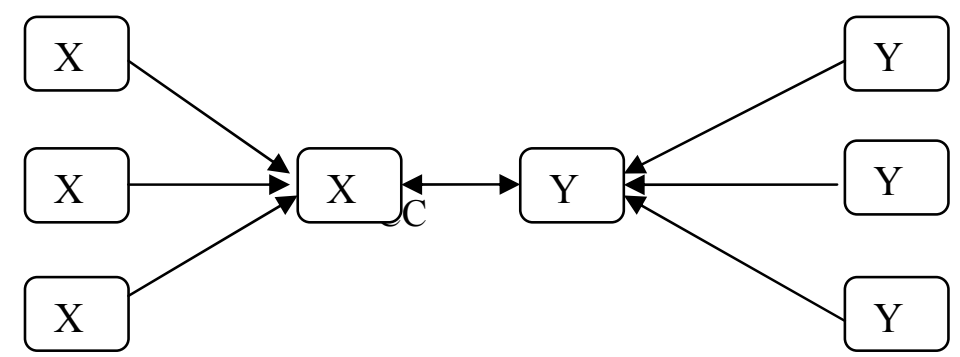

Gambar 1 Korelasi Interdependensi Paradigma Penelitian

Dengan persamaan simultan multivariatnya adalah sebagai berikut:

$$
X 1+X 2+X 3=Y 1+Y 2+Y 3
$$

\section{HASIL DAN PEMBAHASAN}

\section{Kalibrasi Data}

Berdasarkan jumlah kuesioner yang dikembalikan dan terisi penuh, didapat 50 kelompok member dan 55 non member, dan diputuskan untuk menggunakan masing-masing sebanyak 50 responden saja, data ini kemudian dikalibrasi. Oleh karena penelitian ini hanya menganalisis kelompok member, maka data kelompok non member tidak akan dianalisis.

Hasil kalibrasi dengan uji validitas (Pearson Product Moment) dan reliabilitas (Alpha Cronbach) menunjukkan bahwa untuk kelompok member, hanya 21 butir variabel saja yang layak dan dapat diandalkan untuk dijadikan data yang akan dianalisis. Data yang telah dikalibrasi kemudian diuji kadar normalitasnya dengan uji Kolmogorov-Smirnov. Hasilnya menunjukkan bahwa kelompok member tidak berdistribusi normal (untuk $\mathrm{n}=50$ ). Akan tetapi, dengan menghilangkan data sebanyak 5 responden yang outliers, maka data menjadi berdistribusi normal. Dengan demikian, selanjutnya untuk member jumlah respondennya sebanyak 45. Uji Multikolinieritas dan Heterokodesitas menunjukkan bahwa tidak terdapat multikolinieritas antar variabel dan data bersifat monokedesitas, dan secara umum dapat dianalisis lebih lanjut.

\section{Analisis Data}

Berdasarkan data pada tabel lampiran 1, dianalisis dengan menggunakan alat analisis Korelasi Pearson (analisis dependensi), Canonical Correlation (analisis interdependensi), dan hybrid interkorelasi hasilnya sebagaimana pada tabel berikut ini. 
Tabel 3 Nilai Koefisien Pengaruh dan Canonical Correlation

\begin{tabular}{|c|c|c|c|c|}
\hline Variabel & $\mathbf{R}$ (t-test) & $\mathbf{R}^{2}$ & $\mathrm{CC}$ & $\sum \mathbf{R}$ \\
\hline $\mathrm{X} 1$ (Wagon effect) & $0,47(0,00)$ & 0,22 & \multirow{3}{*}{$-0,08(0,00)$} & \multirow{3}{*}{0,82} \\
\hline X2(Snob effect) & $0,36(0,00)$ & 0,13 & & \\
\hline X3(Veblen effect) & $-0,68(0,00)$ & 0,46 & & \\
\hline$X 1 \rightarrow X 2(s)$ & $0,29(0,00)$ & 0,08 & \multirow[t]{3}{*}{$\mathrm{CC}^{2}=0,01$} & \\
\hline$X 1 \rightarrow X 3(j)$ & $-0,62(0,29)$ & 0,38 & & \\
\hline \multirow[t]{6}{*}{$X 2 \rightarrow X 3(j)$} & $-0,08(0,00)$ & 0,01 & & \\
\hline & & & Mean $\mathrm{R}^{2}$ & 0,27 \\
\hline & & & \multirow{4}{*}{ Redundancy Index } & $\begin{array}{c}0,0027 \\
\left(\sum x \rightarrow y\right)\end{array}$ \\
\hline & & & & $0,0022(x 1 \rightarrow y)$ \\
\hline & & & & $0,0013(x 2 \rightarrow y)$ \\
\hline & & & & $0,0046(x 3 \rightarrow y)$ \\
\hline
\end{tabular}

$\mathrm{CC}=$ Canonical Correlation

Nilai korelasi di atas menunjukkan bahwa efek ikut-ikutan memberikan pengaruh langsung sebesar 22\% terhadap keputusan pembelian. Pengaruh itu bersifat trade on, artinya keputusan pembelian dalam konteks responden dengan Supermarket X sebesar 22\% disebabkan langsung oleh efek ikut-ikutan, sedangkan sisanya dipengaruhi faktor lain. Naiknya permintaan karena dorongan ikut arus ini menunjukkan bahwa harga yang berlaku di Supermarket $\mathrm{X}$ tersebut tidak rendah dan juga tidak terlalu tinggi.

Efek gengsi secara langsung memberikan pengaruh terhadap keputusan pembelian sebesar 13\% dan bersifat trade on, artinya keputusan pembelian responden di Supermarket X dalam konteks ini disebabkan langsung oleh faktor gengsi, sedangkan selebihnya disebabkan oleh faktor lain, yang mungkin saja disebabkan oleh faktor yang ada dalam variabel penelitian ini atau di luarnya. Naiknya permintaan karena efek gengsi menunjukkan bahwa belanja di Supermarket X adalah perlambang harkat dan martabat ekonomi yang tinggi dan karenanya memberikan rasa bangga atasnya, dan juga kondisi ini menujukan bahwa $13 \%$ rasa gengsi ini menunjukkan bahwa harga yang relatif berpengaruh sebesar $13 \%$ untuk meningkatkan permintaan.

Efek Veblen atau efek pamer memberikan kontribusi langsung terhadap keputusan pembelian sebesar 46\%, akan tetapi bersifat trade off, artinya untuk setiap kenaikan sifat pamer dalam berkonsumsi, maka keputusan pembelian akan menurun sebesar $46 \%$ atasnya. Hasil ini menunjukkan bahwa untuk setiap penurunan tingkat permintaan, maka semakin besar efek gengsinya. Penurunan ini berindikasi bahwa hanya orang tertentu saja yang mendapatkan manfaat langsung atas efek pamer ini (mungkin maksudnya adalah bahwa meskipun orang miskin sekalipun memiliki rasa ingin pamer atas kemampuannya, akan tetapi adalah tidak pantas atasnya karena nilai kontribusi itu menunjukkan bahwa bila harga naik sebesar $46 \%$, maka permintaan akan menurun, dan sebaliknya $46 \%$ kenaikan harga itu justru akan meningkatkan permintaan dari orang-orang yang layak pamer).

Perhatikan nilai kontribusi 3 variabel di atas, jumlahnya kurang dari 1, artinya secara umum variabel di atas dapat berpengaruh secara bersama-sama (simultan) terhadap keputusan pembelian. Akan tetapi, bila ditilik dari nilai kepekaan silang antara efek/variabel tersebut, maka dapat diketahui bahwa antara variabel X1 dan X2 bersifat saling mengganti $(s=$ substitusi), sedangkan antara X1 terhadap X3 dan X2 terhadap X3 bersifat antara $(j=$ junction $=$ antara $)$. Sifat antara ini berarti membutuhkan variabel intevening atau variabel moderat atau paling tidak membutuhkan variabel binary atau variabel dummy. Untuk kasus di mana diabaikan sifat hubungan antar barang tersebut maka model simultan untuk variabel di atas adalah:

$$
Y=a+b_{1} X_{1}+b_{2} X_{2}++b_{2} X_{2}+e
$$


Hasil analisis data secara simultan dicantumkan pada tabel berikut ini:

Tabel 4 Tabel ANOVA Atas 3 Efek Non Fungsional Demand

\section{SUMMARY OUTPUT}

\begin{tabular}{cc}
\multicolumn{2}{c}{ Regression Statistics } \\
Multiple R & 0,75 \\
R Square & 0,56 \\
Adjusted R & 0,52 \\
Square & \\
Standard Error & 0,17 \\
Observations & 45,00
\end{tabular}

\begin{tabular}{|c|c|c|c|c|c|c|}
\hline \multicolumn{7}{|l|}{ ANOVA } \\
\hline & $d f$ & SS & MS & $F$ & Sig. $F$ & Yes All \\
\hline Regression & 3,00 & 1,47 & 0,49 & 17,07 & 0,00 & $\mathrm{Ha}$ \\
\hline Residual & 41,00 & 1,18 & 0,03 & & & \\
\hline \multirow[t]{2}{*}{ Total } & 44,00 & 2,65 & & & & \\
\hline & Coeff & $S E$ & t Stat & $\begin{array}{c}P- \\
\text { value }\end{array}$ & yes & \\
\hline Intercept & 7,80 & 3,43 & 2,27 & 0,03 & $\mathrm{Ha}$ & \\
\hline $\mathrm{X}$ Variable 1 & $-0,10$ & 0,40 & $-0,24$ & 0,81 & Ho & \\
\hline $\mathrm{X}$ Variable 2 & 1,18 & 0,41 & 2,88 & 0,01 & $\mathrm{Ha}$ & \\
\hline $\mathrm{X}$ Variable 3 & $-1,54$ & 0,30 & $-5,05$ & 0,00 & $\mathrm{Ha}$ & \\
\hline
\end{tabular}

Berdasarkan tabel ini, dapat diketahui bahwa nilai $R^{2}$ simultan adalah sebesar 0,56 dengan penyesuaian sebesar 0,04 yang dapat diartikan bahwa secara bersama-sama 3 efek non fungsional ini memberikan pengaruh langsung terhadap keputusan pembelian sebesar $56 \%$, sementara sisanya ditentukan oleh faktor lain yang tidak dijelaskan dalam penelitian ini. Perhatikanlah pengaruh langsung secara simultan nilai kontribusinya lebih baik dari pada bila efek itu berpengaruh sendirisendiri.

Berdasarkan tabel ini, juga dapat dilihat model prediksi efek tersebut terhadap keputusan pembelian yang parameternya (slope) tidak signifikan adalah variabel, kecuali intercept nya (konstanta). Dengan demikian, model simultan 3 prediktor tersebut adalah:

$$
Y=7,80+1,18 X_{2}-1,54 X_{3}+e
$$

Oleh karena besarnya kontribusi langsung 3 efek non fungsional terhadap keputusan pembelian adalah sebesar 0,56 , maka model prediksi di atas menjadi:

$$
Y=7,80+1,18(0,56) X_{2}-1,54(0,56) X_{3}+e
$$

Perhatikan kembali Tabel 3 di atas, kita bisa menentukan pengaruh sesungguhnya dari variabel efek non fungsional demand itu terhadap keputusan pembelian dengan cara menentukan indeks kelebihan (redundancy index) atas pengaruh langsungnya dengan interpretasi sebagai berikut. Pengaruh langsung 
keputusan pembelian terhadap 3 efek non fungsional demand secara bersama-sama adalah sebesar 1\%, artinya keputusan pembelian membentuk efek ikut arus, gengsi, dan pamer secara bersama-sama sebesar 1\%, bahwa untuk setiap pembelian yang dilakukan konsumen pada Supermarket X tersebut akan menyebabkan faktor ikut arus, gengsi, dan pamer turun sebesar $1 \%$. Pembelian yang terus menerus menyebabkan barang-barang di Supermarket tersebut tidak lagi memiliki kekhususan tersendiri sehingga akan menurunkan dampak gengsi dan pamernya, akibatnya ikut arus pun turun juga.

Untuk pengaruh langsung efek non fungsional demand terhadap keputusan pembelian sebesar $0,27 \%$. Artinya, untuk setiap kenaikan 3 efek tersebut secara bersama-sama, maka rata-rata keputusan pembelian akan turun sebesar $0,27 \%$. Hal ini mengindikasikan bahwa bila efek ikut arus naik, maka efek gengsi akan naik. Akan tetapi, kenaikan ikut arus ini kebanyakan karena penurunan harga, demikian juga dengan efek gengsi. Turunnya harga ini jelas tidak menguntungkan untuk pamer sehingga secara keseluruhan akan memberikan pengaruh negatif terhadap keputusan pembelian. Bila diperhatikan satu persatu, maka rata-rata $0,2 \%$ penurunan keputusan pembelian disebabkan oleh efek ikut arus, $0,13 \%$ disebabkan oleh efek gengsi, dan $0,46 \%$ disebabkan oleh efek pamer. Secara kanonik, dapat dilihat bahwa nilai pengaruh antar variabel ini (interdependensi) relatif sangat kecil dibandingkan dengan pengaruh dependensi $\mathrm{X}$ terhadap $\mathrm{Y}$. Hal ini mengindikasikan bahwa pengaruh causalitas resiprok antara $\mathrm{X}$ dan $\mathrm{Y}$ tidaklah begitu besar manfaat antar keduanya.

Dengan memperhatikan analisis pada bagian ini, dapat diketahui bahwa efek mode, gengsi, dan pamer berpengaruh (dependensi) secara signifikan terhadap keputusan pembelian meskipun pengaruhnya relatif kecil saja, dan berpengaruh secara bersama-sama yang nilainya lebih baik dibandingkan secara sendiri-sendiri. Sebelum mengambil kesimpulan atas analisis ini, dengan memperhatikan lampiran 2 yang memuat hasil analisis pada penelitian ini dengan hasil analisis pada penelitian yang dilakukan oleh saudara Aloysius Amanta terlihat bahwa nilai pengaruh variabel non fungsional demand terhadap keputusan pembelian untuk kelompok member relatif tidak berbeda, baik dengan menggunakan alat non parametrik, maupun dengan parametrik.

\section{SIMPULAN}

Berdasarkan analisis data, maka dapat diketahui bahwa secara statistik (1) Efek mode, gengsi, dan pamer berpengaruh (dependensi dan interdependensi) secara signifikan terhadap keputusan pembelian; dan (2) Efek mode, gengsi, dan pamer berpengaruh secara bersama-sama (gabungan) terhadap keputusan pembelian. Penelitian ini tidak secara khusus meneliti faktor-faktor variat untuk variabel keputusan pembelian (permintaan) sehingga itulah sebabnya dalam penelitian ini loading factornya diasumsikan sama dengan 1, disarankan bagi peneliti yang berminat untuk menganalisis seperti penelitian ini dengan objek yang berbeda melakukan identifikasi variat yang mendominasi keputusan pembelian sehingga dalam analisisnya akan bisa memberikan simpulan yang dapat dimanfaatkan secara langsung oleh yang berkepentingan.

Hasil penelitian ini setidaknya memberikan gambaran bahwa betapa sebenarnya terdapat halhal yang perlu diperhatikan dari sekedar hanya persoalan harga atas permintaan konsumen. Keputusan tentang menaikan atau menurunkan harga jual produk untuk meningkatkan penjualan harus mempertimbangkan faktor non fungsional ini sebab bila produsen khususnya, mengabaikan sinyalemen ini produsen akan kehilangan momen untuk memanfaatkan peluang pasar. Sekedar contoh, cobalah perhatikan penjualan HP merek Siemen yang tahun 2001-2002 sempat mendominasi pasarnya dengan tipe $\mathrm{C}$ nya, tapi hilang ditelan persaingan. HP Nokia yang dikalahkan BB, Nexian yang mulai mendominasi pasar dengan tampilan BB dengan kualitas atas dan harga standar, dan masih banyak lainnya. Perhatikan kembali bahwa permintaan turun atau naik bukan karena naik atau turunnya harga dan tidak ada kondisi ceteris paribus dalam pasar yang realistis. 


\section{DAFTAR PUSTAKA}

Aloysius Albert A, 2009, Analisis Pengaruh Permintaan Non Fungsional Terhadap Keputusan Pembelian Konsumen - Skripsi, BINUS Jakarta

Putong 1. (2003). Pengantar ekonomi mikro dan makro, Jakarta: Ghalia Indonesia.

Putong 2. (2009). Economics: Pengantar mikro dan makro, Jakarta: MWM.

Putong 3. (2005). Teori ekonomi mikro, Jakarta: MWM.

Santoso, S. (2010). Statistik multivariat, Jakarta: ElekMediaKomputindo.

Sarwoko. (2010). Dasar-dasar ekonometrika, Yogyakarta: Penerbit ANDI. 


\section{LAMPIRAN}

Tabel A.1 Data Olahan Responden Member untuk Efek Non Fungsional dan Demand

\begin{tabular}{|c|c|c|c|c|c|}
\hline Variabel & $\begin{array}{c}\text { Wagon } \\
\text { effect }\end{array}$ & $\begin{array}{l}\text { Snob } \\
\text { effect }\end{array}$ & $\begin{array}{c}\text { Veblen } \\
\text { effect }\end{array}$ & Mean & Demand \\
\hline Responden & $\mathbf{X} 1$ & $\mathrm{X} 2$ & X3 & $\mathbf{X}$ & $\mathbf{Y}$ \\
\hline 01 & 5,05 & 5,22 & 5,22 & 5,16 & 5,25 \\
\hline 02 & 5,08 & 5,27 & 5,28 & 5,21 & 5,31 \\
\hline 03 & 5,08 & 5,28 & 5,28 & 5,21 & 5,31 \\
\hline 04 & 5,06 & 5,25 & 5,26 & 5,19 & 5,30 \\
\hline 05 & 5,10 & 5,20 & 5,22 & 5,17 & 5,32 \\
\hline 06 & 5,04 & 5,17 & 5,19 & 5,13 & 5,33 \\
\hline 07 & 5,09 & 5,16 & 5,18 & 5,14 & 5,35 \\
\hline 08 & 5,07 & 5,20 & 5,18 & 5,15 & 5,36 \\
\hline 09 & 5,11 & 5,23 & 5,18 & 5,17 & 5,37 \\
\hline 10 & 5,13 & 5,25 & 5,14 & 5,17 & 5,37 \\
\hline 11 & 5,11 & 5,25 & 5,20 & 5,19 & 5,38 \\
\hline 12 & 5,12 & 5,31 & 5,23 & 5,22 & 5,47 \\
\hline 13 & 5,18 & 5,34 & 5,29 & 5,27 & 5,54 \\
\hline 14 & 5,25 & 5,34 & 5,27 & 5,28 & 5,59 \\
\hline 15 & 5,18 & 5,32 & 5,23 & 5,25 & 5,59 \\
\hline 16 & 5,09 & 5,23 & 5,15 & 5,16 & 5,57 \\
\hline 17 & 5,10 & 5,25 & 5,11 & 5,15 & 5,65 \\
\hline 18 & 5,09 & 5,25 & 5,11 & 5,15 & 5,68 \\
\hline 19 & 5,14 & 5,34 & 5,20 & 5,23 & 5,75 \\
\hline 20 & 5,14 & 5,35 & 5,16 & 5,22 & 5,73 \\
\hline 21 & 5,07 & 5,38 & 5,16 & 5,20 & 5,70 \\
\hline 22 & 5,01 & 5,33 & 5,11 & 5,15 & 5,72 \\
\hline 23 & 4,96 & 5,34 & 5,14 & 5,15 & 5,76 \\
\hline 24 & 4,98 & 5,33 & 5,16 & 5,16 & 5,80 \\
\hline 25 & 5,05 & 5,36 & 5,19 & 5,20 & 5,79 \\
\hline 26 & 5,10 & 5,39 & 5,22 & 5,23 & 5,79 \\
\hline 27 & 5,16 & 5,38 & 5,20 & 5,25 & 5,78 \\
\hline 28 & 5,13 & 5,37 & 5,15 & 5,22 & 5,78 \\
\hline 29 & 5,18 & 5,36 & 5,11 & 5,22 & 5,77 \\
\hline 30 & 5,21 & 5,37 & 5,06 & 5,21 & 5,78 \\
\hline 31 & 5,23 & 5,40 & 5,07 & 5,23 & 5,78 \\
\hline 32 & 5,24 & 5,38 & 5,05 & 5,22 & 5,74 \\
\hline 33 & 5,23 & 5,38 & 5,04 & 5,22 & 5,70 \\
\hline 34 & 5,24 & 5,36 & 5,02 & 5,21 & 5,71 \\
\hline 35 & 5,26 & 5,36 & 5,02 & 5,21 & 5,71 \\
\hline 36 & 5,28 & 5,37 & 5,05 & 5,23 & 5,73 \\
\hline 37 & 5,27 & 5,37 & 5,01 & 5,22 & 5,74 \\
\hline 38 & 5,28 & 5,37 & 5,01 & 5,22 & 5,79 \\
\hline 39 & 5,27 & 5,34 & 4,99 & 5,20 & 5,78 \\
\hline 40 & 5,25 & 5,34 & 4,98 & 5,19 & 5,70 \\
\hline 41 & 5,25 & 5,32 & 4,97 & 5,18 & 5,77 \\
\hline 42 & 5,27 & 5,34 & 5,03 & 5,21 & 5,74 \\
\hline 43 & 5,26 & 5,34 & 5,03 & 5,21 & 5,71 \\
\hline 44 & 5,27 & 5,32 & 5,00 & 5,20 & 5,62 \\
\hline 45 & 5,23 & 5,28 & 4,92 & 5,14 & 5,72 \\
\hline 46 & 5,22 & 5,24 & 4,92 & 5,13 & 5,80 \\
\hline 47 & 5,22 & 5,26 & 4,93 & 5,14 & 6,17 \\
\hline 48 & 5,22 & 5,25 & 4,92 & 5,13 & 6,11 \\
\hline 49 & 5,24 & 5,25 & 4,97 & 5,15 & 6,17 \\
\hline 50 & 5,26 & 5,24 & 5,01 & 5,17 & 6,33 \\
\hline
\end{tabular}


Tabel A.2 Nilai Korelasi Non Parametrik dan Parametrik

\begin{tabular}{cccccc}
\hline \multirow{2}{*}{ Variabel } & \multicolumn{2}{c}{ Non-Parametrik* } & \multicolumn{2}{c}{ Parametrik } & \multirow{2}{*}{ Selisih } \\
\cline { 2 - 5 } & $\mathbf{R}$ & $\mathbf{R}^{2}$ & $\mathbf{R}$ & $\mathbf{R}^{2}$ & \\
X1 & 0,393 & 0,15 & $0,47(0,00)$ & 0,22 & $-0,07$ \\
X2 & 0,440 & 0,19 & $0,36(0,00)$ & 0,13 & $-0,06$ \\
X3 & $-0,594$ & 0,35 & $-0,68(0,00)$ & 0,46 & $-0,11$ \\
& & & & & $t-$ test $=0,55$ \\
\hline
\end{tabular}

*Nilai dari analisis dalam Skripsi Aloysius Amanta (2009). Diolah kembali 